\title{
Soil respiration patterns and rates at three Taiwanese forest plantations: dependence on elevation, temperature, precipitation, and litterfall
}

\author{
Yu-Hsuan Huang ${ }^{1}$, Chih-Yu Hung ${ }^{1}$, I-Rhy Lin ${ }^{1}$, Tomonori Kume ${ }^{1}$, Oleg V. Menyailo ${ }^{2}$ and Chih-Hsin Cheng ${ }^{\text {** }}$
}

\begin{abstract}
Background: Soil respiration contributes to a large quantity of carbon emissions in the forest ecosystem. In this study, the soil respiration rates at three Taiwanese forest plantations (two lowland and one mid-elevation) were investigated. We aimed to determine how soil respiration varies between lowland and mid-elevation forest plantations and identify the relative importance of biotic and abiotic factors affecting soil respiration.

Results: The results showed that the temporal patterns of soil respiration rates were mainly influenced by soil temperature and soil water content, and a combined soil temperature and soil water content model explained 54-80\% of the variation. However, these two factors affected soil respiration differently. Soil temperature positively contributed to soil respiration, but a bidirectional relationship between soil respiration and soil water content was revealed. Higher soil moisture content resulted in higher soil respiration rates at the lowland plantations but led to adverse effects at the mid-elevation plantation. The annual soil respiration rates were estimated as $14.3-20.0 \mathrm{Mg} \mathrm{Cha}^{-1} \mathrm{year}^{-1}$ at the lowland plantations and 7.0-12.2 $\mathrm{MgC} \mathrm{Cha}^{-1}$ year $^{-1}$ at the mid-elevation plantation. When assembled with the findings of previous studies, the annual soil respiration rates increased with the mean annual temperature and litterfall but decreased with elevation and the mean annual precipitation. A conceptual model of the biotic and abiotic factors affecting the spatial and temporal patterns of the soil respiration rate was developed. Three determinant factors were proposed: (i) elevation, (ii) stand characteristics, and (iii) soil temperature and soil moisture.
\end{abstract}

Conclusion: The results indicated that changes in temperature and precipitation significantly affect soil respiration. Because of the high variability of soil respiration, more studies and data syntheses are required to accurately predict soil respiration in Taiwanese forests.

Keywords: Soil respiration, Elevation, Soil temperature, Soil water content, Litterfall, Temperature sensitivity

\section{Introduction}

Soil respiration, which refers to the efflux of carbon dioxide from the soil surface to the atmosphere, is a crucial component of carbon cycling. It is the primary pathway through which carbon moves from the ecosystem into the atmosphere, and it strongly affects the carbon balance and turnover (Raich and Schlesinger 1992; Davidson

\footnotetext{
*Correspondence: chengch@ntu.edu.tw

1 School of Forestry and Resource Conservation, National Taiwan University, Taipei 106, Taiwan

Full list of author information is available at the end of the article
}

and Janssens 2006; Bond-Lamberty and Thomson 2010). In the forest ecosystem, the soil contributes to $60-80 \%$ of total ecosystem respiration (Law et al. 1999; Janssens et al. 2001). Understanding the rate of carbon release from the soil and its seasonal patterns will lead to a comprehensive understanding of how to tackle regional and global climate change.

Soil respiration is produced mainly by plant roots and soil organisms. The soil respiration rates are largely dependent on soil temperature and soil water content. Most related studies have shown that soil respiration is 
positively correlated with soil temperature (Davidson et al. 1998), and that it can be modified or even impeded by soil water content under very wet or very dry conditions (Davidson et al. 2000; Raich and Schlesinger 1992). The effects of soil temperature and soil water content on soil respiration have been suggested to be interactive, rather than individual (Raich and Schlesinger 1992; Davidson et al. 1998; Reichstein et al. 2003; Saiz et al. 2006). Global meta-analysis data indicated that soil respiration is significantly correlated with mean annual temperature (MAT) and mean annual precipitation (MAP) (Raich and Schlesinger 1992) and possibly also with three variables-MAT, MAP, and vegetation productivity (Raich and Schlesinger 1992; Reichstein et al. 2003; Bond-Lamberty and Thomson 2010). However, the majority of these studies were conducted in temperate ecosystems; fewer measurements have been taken in the tropics and subtropics. Some measurements taken in the tropics and subtropics demonstrated a high deviation between measurements and estimations made using global regression models, with the differences ranging from -73 to $+294 \%$ (Hashimoto et al. 2004; Chang et al. 2008; Katayama et al. 2009; Tan et al. 2013). These statistics exemplify the inherent variability of soil respiration in the tropics and subtropics; thus, soil resperation in these regions should be further investigated.

Because of the high cost of measurement instruments and the complex landscape, soil respiration has not been extensively investigated in Taiwan (Chang et al. 2008; Kao and Chang 2009; Hsieh et al. 2016). Therefore, soil respiration in different areas and its seasonal dynamics are not widely understood. In Taiwan, the temperature decreases with elevation, with a lapse rate of $-5.3{ }^{\circ} \mathrm{C} \mathrm{km}^{-1}$. However, precipitation increases with elevation, with mountainous areas and lowlands receiving 2000-3500 and 1500-2000 mm of annual rainfall, respectively (Lee et al. 2004). Such climatic differences associated with their influences over primary production may have significant impacts on soil respiration on spatial and temporal scales. The mechanisms underlying the effects of these factors on soil respiration must be determined to enable the assessment of the interaction between climate and soil respiration and the processes involved in the interaction. Moreover, measuring the soil respiration rates in Taiwan would ensure the completeness of the global database, particularly for databases for tropical and subtropical ecosystems (Raich and Schlesinger 1992; BondLamberty and Thomson 2010).

In this study, soil respiration at three forest plantations (two lowland and one mid-elevation) was investigated throughout an annual cycle. Soil temperature, soil water content, and litterfall production were also determined at each plantation. We investigated the soil respiration rate at each plantation and compared the rate among the plantations. Our objectives were as follows: (1) to determine how soil respiration varies between lowland and mid-elevation forest plantations, (2) to analyze the relative importance of soil temperature and soil moisture for temporal soil respiration patterns at the three studied plantations, and (3) to assess which factors are crucial for controlling the annual soil respiration rate across the plantations.

\section{Materials and methods Study sites}

The first plantation in this study is located in the lowland plain in Rende District, Tainan (TN; $22^{\circ} 56^{\prime} \mathrm{N}, 120^{\circ} 16^{\prime} \mathrm{E}$ ). This plantation was originally an orchard but had been abandoned for more than 15 years. It is now used as a representative plantation for predicting potential growth in current cropland afforestation areas because no such old plantation exists in Taiwan (Lin et al. 2011; Cheng et al. 2016a). Two stands, TN1 and TN2, were evaluated. TN1 is an abandoned lychee (Litchi chinensis) plantation with a stand age of 33 years. TN2 is an abandoned wax apple (Eugenia javanica) plantation with a stand age of 25 years. Because of the long-term abandonment, understory vegetation such as Macaranga tanarius, Murraya paniculata, Celtis sinensis, Panicum maximum, and Alpinia speciose grows rigorously at both stands.

The second plantation is located in the Datu tableland, Taichung (TC; $24^{\circ} 17^{\prime} \mathrm{N}, 120^{\circ} 35^{\prime} \mathrm{E}$ ). This plantation is an Acacia confusa plantation situated at an elevation of $150 \mathrm{~m}$ above sea level. Two adjacent stands, TC1 and TC2, were studied. Both stands have the same Acacia overstory but differ in their understory vegetation because of the influence of fire disturbance and invasive grass. TC1 has not been disturbed by fire, and the dominant understory species are Lantana camara, Zanthoxylum nitidum, Mallotus repandus, and Glochidion rubrum. However, TC2 has been slightly influenced by ground fire, and the understory vegetation (more than $90 \%$ coverage) has been replaced by grass (Panicum maximum) (Cheng et al. 2013a).

The third plantation is located in mid-elevation montane areas in Xitou, Nantou $\left(\mathrm{NT} ; 23^{\circ} 40^{\prime} \mathrm{N}, 120^{\circ} 46^{\prime} \mathrm{E}\right)$. The plantation is a Japanese cedar (Cryptomeria japonica) plantation situated at an elevation of approximately $1200 \mathrm{~m}$ above sea level. Three stands, NT1, NT2, and NT3, were studied. The stand ages of which are 90, 63, and 40 years, respectively, at the time of this study. In these three stands, the mean diameter at breast height $(\mathrm{DBH})$, basal area, and living tree biomass carbon stocks increase with stand age. By contrast, tree density decreases with stand age (Cheng et al. 2013b) (Table 1). 


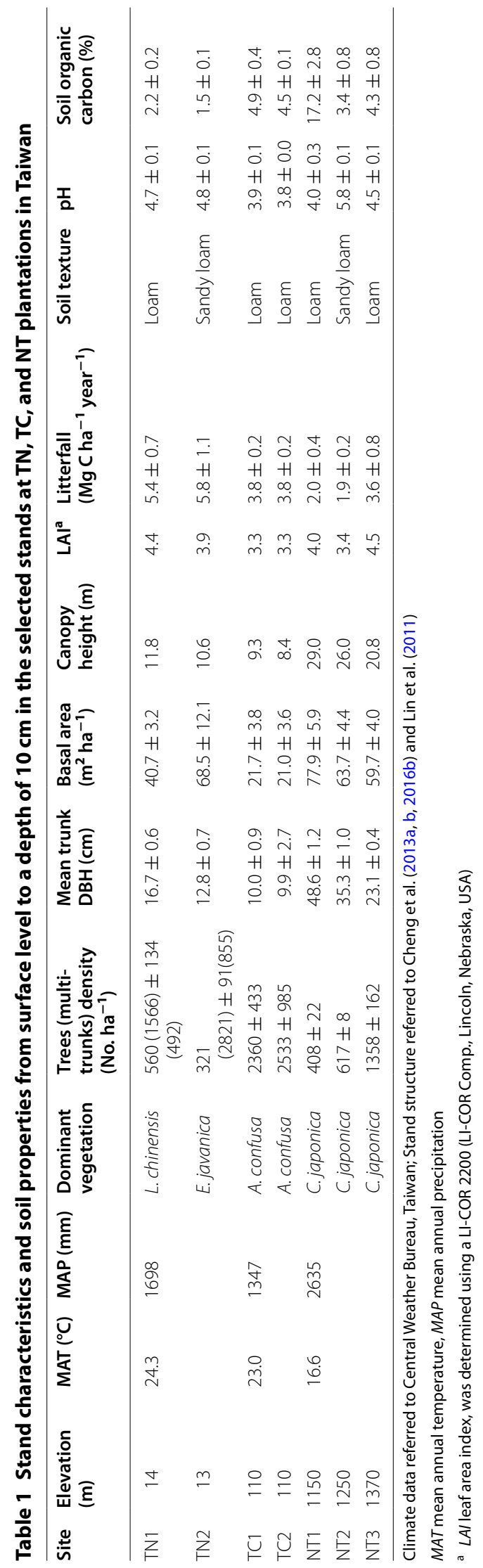


Elevation, MAT, and MAP at the three study plantations are shown in Table 1 . MAT is strongly affected by elevation and ranges from $16.6{ }^{\circ} \mathrm{C}$ at NT to $25.0^{\circ} \mathrm{C}$ at TN. Elevation also exerts a significantly orographic influence on precipitation. A higher MAP was found at the midelevation NT plantation $(2635 \mathrm{~mm})$ than at the lowland plantations at TN $(1698 \mathrm{~mm})$ and TC $(1347 \mathrm{~mm})$. The climatic conditions at both $\mathrm{TN}$ and $\mathrm{TC}$ correspond to tropical and subtropical moist forests, and the climatic condition at NT is classified as a montane wet subtropical forest.

Previously studied stand characteristics and soil properties are shown in Table 1 (Lin et al. 2011; Cheng et al. 2013a, b, 2016b). Generally, all selected stands were closed canopy with leaf area indices between 3.3 and 4.5. The canopy height ranged between 8.4 and $29.0 \mathrm{~m}$, and the mean stem DBH ranged between 9.9 and $48.6 \mathrm{~cm}$. The soil textures were loam and sandy loam. Stand productivity was evaluated based on aboveground litterfall production, which has been correlated to the total net primary production and has been used to represent the labile input available to decomposition under a forest ecosystem in previous studies (Bond-Lamberty and Thomson 2010). Annual aboveground litterfall production over study stands ranged between 1.9 and $5.8 \mathrm{Mg} \mathrm{C} \mathrm{ha}^{-1}$ (Table 1). Higher litterfall production was found at TC and TN than at NT.

In 2010, the mean air temperature was 24.6, 23.0, and $17.0^{\circ} \mathrm{C}$, and the total precipitation was 1778,1182 , and $2041 \mathrm{~mm}$ at TN, TC, and NT, respectively (Fig. 1). The annual air temperature and precipitation at TN and TC in 2010 were consistent with their long-term climate regimes, but lower precipitation was found at NT (2041 vs. $2500 \mathrm{~mm}$ ) because of lower precipitation in summer. Generally, a hot and humid season from April to September and a cold and dry season from October to March can be observed at all three plantations.

\section{Soil respiration}

Soil respiration was measured using a Li-6400 with a Li-6400-09 soil chamber (LI-COR Inc., Lincoln, Nebraska, USA). Measurements were taken using polyvinyl chloride (PVC) collars that were $11 \mathrm{~cm}$ in diameter and $7 \mathrm{~cm}$ in height. The collars were installed on the soil surface at a depth of $5 \mathrm{~cm}$ to prevent erosion from heavy rainfall and enable the growth of fine roots. Six PVC collars (duplicates from three $20 \times 20-\mathrm{m}^{2}$ plots) were applied at each stand. The collars were installed 2 months before the first measurement and remained in place throughout the measurement period. Soil respiration at each collar was calculated as the average of three values generated from three continuous cycles. All chamber measurements were conducted between 08:00 and

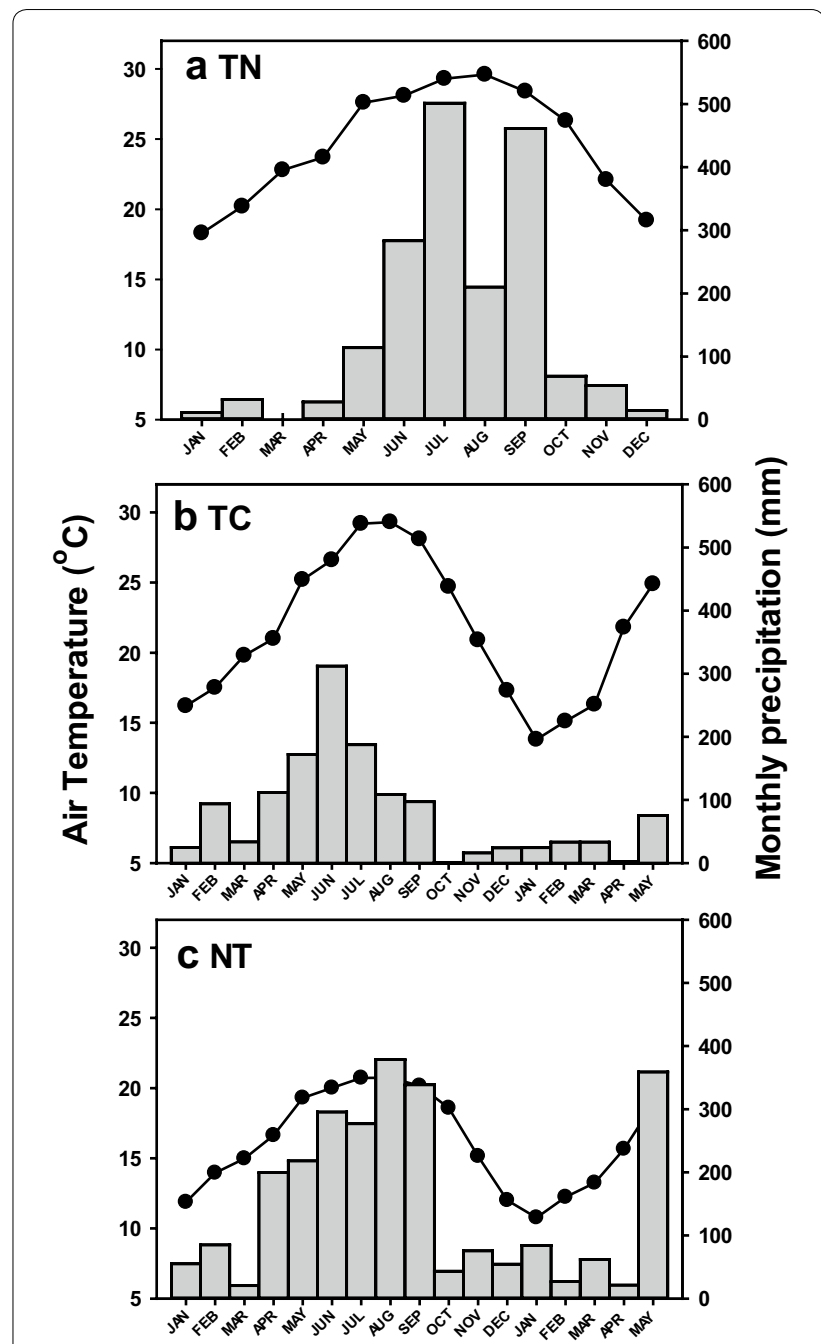

Fig. 1 Monthly mean air temperature $\left({ }^{\circ} \mathrm{C}\right.$, black circle) and precipitation (mm, gray bar) from January 2010 to December 2010 at TN plantation and from January 2010 to May 2011 at TC and NT plantations

14:00 local time to minimize sampling bias introduced by the time of day (Knowles et al. 2015; Hsieh et al. 2016), and measurements were taken monthly from January 2010 to May 2011 at TC and NT and from January 2010 to December 2010 at TN.

The temperature and water content of soil next to each collar were determined during the measurement period. Soil temperature at a depth of $10 \mathrm{~cm}$ was measured using the temperature sensor attached to the Li-6400. Soil water content was measured as volumetric soil moisture content by using time domain reflectometry probes (Hydrosense, Campbell Scientific Inc., Utah, USA). In addition, the full spectra of soil temperature and soil water content were recorded. A data logger (HOBO U30, Onset, Massachusetts, USA) connected to a temperature 
probe (S-TMB-M006, Onset) at a depth of $10 \mathrm{~cm}$ and a soil water content probe (S-SMx-M005, Onset) covering a depth of $0-20 \mathrm{~cm}$ were used at each stand. Both probes were programmed to measure values at 4-min intervals and store data hourly.

\section{Modeling temporal soil respiration patterns}

To determine whether temporal changes in soil respiration are related to soil temperature and soil water content, the relationships between soil respiration and soil temperature and soil water content were examined using three empirical regression models. The first model involved only soil temperature, and an exponential model was applied (Lloyd and Taylor 1994; Sheng et al. 2010).

Soil respiration $\left(\mu \mathrm{mol} \mathrm{CO} \mathrm{m}^{-2} \mathrm{~s}^{-1}\right)=\mathrm{a} \times \exp (\mathrm{b} \times \mathrm{T})$

where $\mathrm{T}$ is soil temperature $\left({ }^{\circ} \mathrm{C}\right)$ at a depth of $10 \mathrm{~cm}$, and a and $b$ are constants fitted using least squares techniques.

The second model used soil water content as the only indicator variable, and a quadratic equation was applied (Saiz et al. 2006).
Soil respiration $=\mathrm{a}+\mathrm{b} \times \theta+\mathrm{c} \times \theta^{2}$

where $\theta$ refers to soil water content $\left(\mathrm{cm}^{3} \mathrm{~cm}^{-3}\right)$ over a surface at a depth of $20 \mathrm{~cm}$, and a and b are constants fitted using least squares techniques.

In the third model, the soil respiration rate is the function of soil temperature and soil water content (Saiz et al. 2006; Sheng et al. 2010). The model is expressed as follows:

$$
\text { Soil respiration }=\mathrm{a} \times \exp (\mathrm{b} \times \mathrm{T}) \times \theta^{\mathrm{c}}
$$

where $\mathrm{T}$ is soil temperature, $\theta$ is soil water content, and $\mathrm{a}$, $\mathrm{b}$, and $\mathrm{c}$ are the model coefficients.

A $Q_{10}$ function was used to determine the temperature-respiration relationship (Lloyd and Taylor 1994). The equation is expressed as follows:

$$
\mathrm{Q}_{10}=\exp (10 \times \mathrm{b})
$$

where $b$ is the model coefficient in Eqs. (1) and (3).

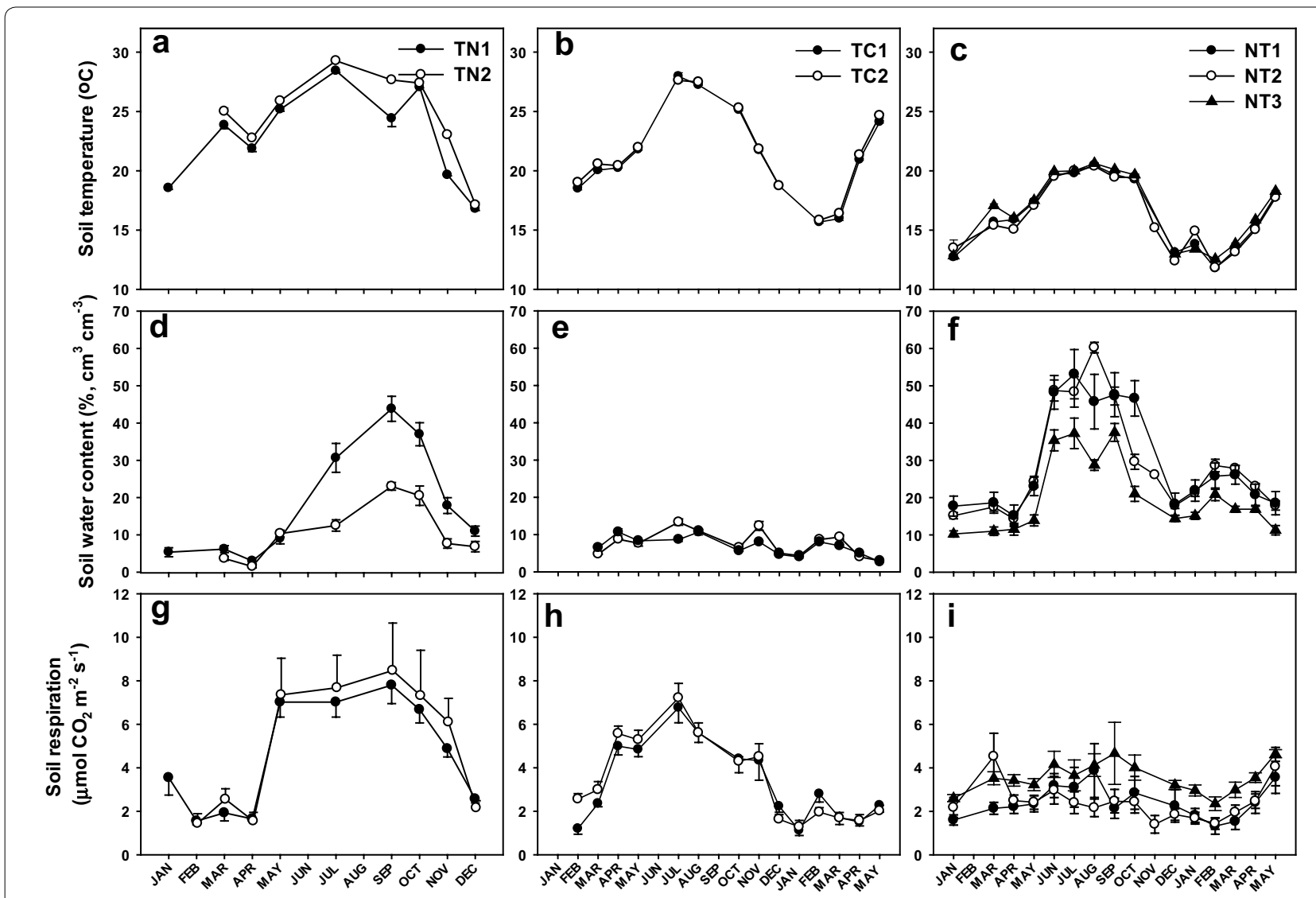

Fig. 2 Seasonal patterns of soil temperature $\left({ }^{\circ} \mathrm{C}\right)$, soil water content $\left(\%, \mathrm{~cm}^{3} \mathrm{~cm}^{-3}\right)$, and soil respiration rate $\left(\mu \mathrm{mol} \mathrm{CO}_{2} \mathrm{~m}^{-2} \mathrm{~s}^{-1}\right)$ at TN $(\mathbf{a}, \mathbf{d}, \mathbf{g}), \mathrm{TC}(\mathbf{b}$ $\mathbf{e}, \mathbf{h})$, and NT $(\mathbf{c}, \mathbf{f}, \mathbf{i})$ plantations in Taiwan. Each symbol is the mean of the measurements, and the standard deviation is plotted as error bars 


\section{Data analysis}

The regression models were fitted using $R$ (2.15.2) to estimate parameters a, b, and c; coefficients of determinations $\left(R^{2}\right)$; and the root mean squared error (RMSE). The $\mathrm{R}^{2}$ and RMSE were used to determine the significance and goodness-of-fit of the models. The soil respiration model was estimated based on the regression model with the highest $\mathrm{R}^{2}$ and the lowest RMSE. We applied the continuous measurements of soil temperature and soil moisture from the data logger to the regressive equation to estimate the amount of carbon released through soil respiration. Although the values of the monthly field measurements and data logger were measured using different instruments and locations, their readings were closely correlated $(r>0.98)$. A linear equation that converted data logger data to field measurements was used before running the regressive equation. The daily soil respiration rate was firstly calculated. The annual soil respiration in 2010 was obtained by calculating the sum of daily estimations (Saiz et al. 2010).

To assess which factors are crucial for controlling the annual soil respiration rates across the plantations, the relationships among annual soil respiration rates, elevation, MAT, and litterfall production were examined. In addition to our study data, data from previous studies that used the same dynamic closed chamber method to measure soil respiration were assembled to generate a more robust relationship (Chang et al. 2008; Kao and Chang 2009; Hsieh et al. 2016).

\section{Results}

Temporal patterns of soil temperature, soil water content, and soil respiration

Soil temperature at a depth of $10 \mathrm{~cm}$ was low in winter and reached its peak in summer (Fig. 2), ranging between 15 and $30{ }^{\circ} \mathrm{C}$ at the lowland TN and TC plantations and between 12 and $20{ }^{\circ} \mathrm{C}$ at the mid-elevation NT plantation. The temporal patterns of soil water content were similar to those of soil temperature at all three plantations, namely high in summer and low in winter (Fig. 2). The highest soil water content was observed at NT, reaching $>50 \% \mathrm{~cm}^{3} \mathrm{~cm}^{-3}$ from June to October because of higher precipitation. The lowest soil water content $\left(<10 \% \mathrm{~cm}^{3} \mathrm{~cm}^{-3}\right)$ was observed at TC and TN from December to March because of lower precipitation. According to monthly field measurements, soil water content at TC was below $15 \% \mathrm{~cm}^{3} \mathrm{~cm}^{-3}$; however, data logger-recorded soil water content ranged between 3 and $34 \% \mathrm{~cm}^{3} \mathrm{~cm}^{-3}$. The lower values of the monthly field measurements may be due to the placement of the probe at the same soil spot, which might have been desiccated after the measurements were taken. Nevertheless, a linear correlation was observed between the monthly field measurements and data logger data $(\mathrm{r}=0.98, \mathrm{p}<0.01)$.

The seasonality of soil respiration rates at the lowland TC and TN plantations coincided strongly with soil temperature and soil water content (Fig. 2). The soil respiration rate in the hot and humid season was significantly

Table 2 Estimated parameters of $a, b$, and $c$; coefficients of determinations $\left(R^{2}\right)$; root mean squared error (RMSE); and temperature sensitivity $\left(Q_{10}\right)$ of regressions for modeling soil respiration at $T N$, $T C$, and NT plantations in Taiwan

\begin{tabular}{|c|c|c|c|c|c|c|c|c|c|c|c|c|}
\hline Model & a & b & C & $\mathbf{R}^{2}$ & RMSE & $\mathrm{Q}_{10}$ & a & b & c & $\mathbf{R}^{2}$ & RMSE & $Q_{10}$ \\
\hline & TN1 & & & & & & TN2 & & & & & \\
\hline Temperature & 0.592 & 0.089 & & 0.430 & 1.965 & 2.44 & 0.269 & 0.120 & & 0.605 & 1.920 & 3.31 \\
\hline Water content & 1.709 & 0.246 & -0.003 & 0.654 & 1.648 & & 0.053 & 0.870 & -0.022 & 0.824 & 1.400 & \\
\hline \multirow[t]{2}{*}{ Temperature and water content } & 0.862 & 0.033 & 0.349 & 0.705 & 1.529 & 1.39 & 0.657 & 0.053 & 0.371 & 0.847 & 1.310 & 1.70 \\
\hline & $\mathrm{TC} 1$ & & & & & & $\mathrm{TC} 2$ & & & & & \\
\hline Temperature & 0.333 & 0.106 & & 0.611 & 1.182 & 2.88 & 0.374 & 0.103 & & 0.573 & 1.359 & 2.80 \\
\hline Water content & 1.073 & 0.095 & 0.032 & 0.565 & 1.290 & & 0.971 & 0.214 & 0.013 & 0.523 & 1.506 & \\
\hline \multirow[t]{2}{*}{ Temperature and water content } & 0.181 & 0.070 & 0.738 & 0.843 & 0.783 & 2.01 & 0.051 & 0.099 & 1.133 & 0.669 & 1.255 & 2.69 \\
\hline & NT1 & & & & & & NT2 & & & & & \\
\hline Temperature & 0.573 & 0.086 & & 0.676 & 0.444 & 2.37 & 1.347 & 0.036 & & 0.100 & 0.826 & 1.44 \\
\hline Water content & 3.864 & -0.138 & 0.002 & 0.336 & 0.663 & & 4.057 & -0.104 & 0.001 & 0.085 & 0.865 & \\
\hline \multirow[t]{2}{*}{ Temperature and water content } & 0.744 & 0.128 & -0.289 & 0.755 & 0.402 & 3.60 & 3.030 & 0.116 & -0.652 & 0.453 & 0.668 & 3.19 \\
\hline & NT3 & & & & & & & & & & & \\
\hline Temperature & 1.394 & 0.055 & & 0.721 & 0.376 & 1.74 & & & & & & \\
\hline Water content & 4.049 & -0.086 & 0.003 & 0.278 & 0.631 & & & & & & & \\
\hline Temperature and water content & 1.515 & 0.065 & -0.086 & 0.748 & 0.373 & 1.92 & & & & & & \\
\hline
\end{tabular}




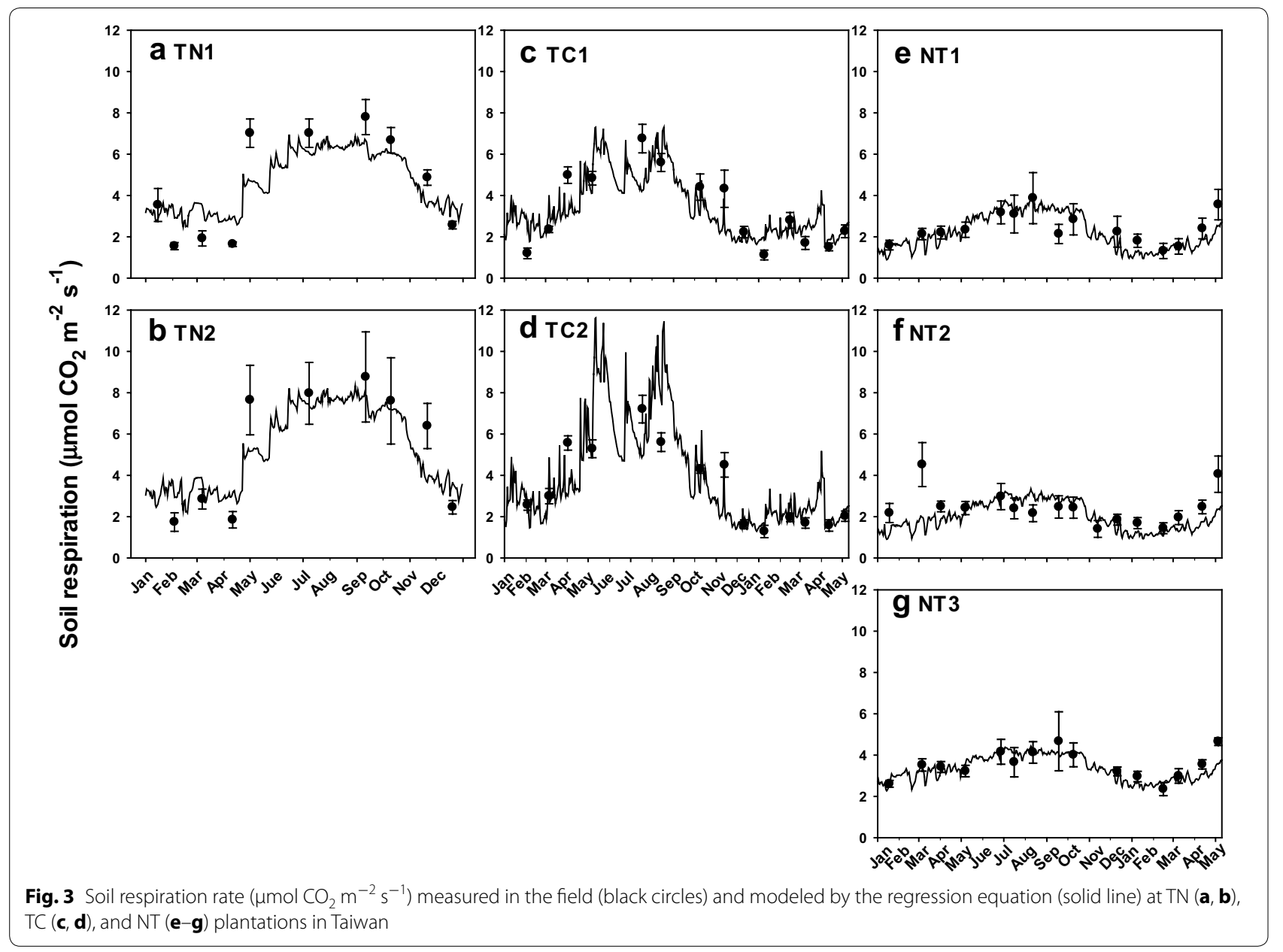

Table 3 Estimated mean soil respiration rate and annual soil respiration rate in 2010 at TN, TC, and NT plantations in Taiwan

\begin{tabular}{lll}
\hline & $\begin{array}{l}\text { Mean soil respiration rate } \\
\left(\boldsymbol{\mu} \mathbf{m o l ~} \mathbf{C O}_{\mathbf{2}} \mathbf{~ m}^{-\mathbf{2}} \mathbf{~}^{-\mathbf{1}}\right)\end{array}$ & $\begin{array}{l}\text { Annual soil respiration } \\
\text { rate }\left(\mathbf{M g ~ C ~}^{-\mathbf{1}} \mathbf{y e a r}^{-\mathbf{1}}\right)\end{array}$ \\
\hline TN1 & 4.67 & 17.6 \\
TN2 & 5.30 & 20.0 \\
TC1 & 3.78 & 14.3 \\
TC2 & 4.58 & 17.3 \\
NT1 & 2.02 & 7.6 \\
NT2 & 1.86 & 7.0 \\
NT3 & 3.22 & 12.2 \\
\hline
\end{tabular}

higher than that in the cold and dry season. The soil respiration rates increased from $2 \mu \mathrm{mol} \mathrm{CO}_{2} \mathrm{~m}^{-2} \mathrm{~s}^{-1}$ in winter to $8 \mu \mathrm{mol} \mathrm{CO} \mathrm{Cm}^{-2} \mathrm{~s}^{-1}$ in summer. However, the soil respiration rate at NT slightly increased from $2 \mu \mathrm{mol} \mathrm{CO} \mathrm{Cm}^{-2} \mathrm{~s}^{-1}$ in winter to $3.5 \mu \mathrm{mol} \mathrm{CO} \mathrm{Cm}^{-2} \mathrm{~s}^{-1}$ in summer.

\section{Regression model of soil respiration}

The soil temperature univariate model explained approximately $60 \%$ of the variations in soil respiration (Table 2 ). The soil water content model explained $52-82 \%$ of the variations at TN and TC but poorly explained those at NT $\left(\mathrm{R}^{2}<34 \%\right)$. The application of a combined soil temperature and soil water content model [Eq. (3)] yielded a higher $\mathrm{R}^{2}$ (54-80\%) and lower RMSE than did the univariate models. This finding suggested a better representation of the relationship by using both soil temperature and soil water content rather than a single factor. The combined models showed that soil temperature positively contributed to soil respiration at all three plantations. However, the models revealed bidirectional relationships between soil respiration and soil water content. Higher soil moisture content at TN and TC resulted in higher soil respiration rates, whereas higher soil water content at NT led to adverse effects and lower soil respiration rates.

The temperature-dependent $\mathrm{Q}_{10}$ values ranged between 2.44 and 3.31 at the lowland TN and TC plantations and 
Table 4 Correlation coefficients at significant level $p<0.01$ for annual soil respiration rate, elevation, mean annual temperature (MAT), mean annual precipitation (MAP), and litterfall production in 10 Taiwanese study stands

\begin{tabular}{|c|c|c|c|c|c|}
\hline & Soil respiration $\left(\mathrm{Mg} \mathrm{Cha}^{-1}\right.$ year $\left.^{-1}\right)$ & Elevation $(\mathrm{m})$ & MAT $\left({ }^{\circ} \mathrm{C}\right)$ & MAP (mm) & Litterfall (Mg C ha ${ }^{-1}$ year $\left.^{-1}\right)$ \\
\hline Soil respiration & 1.00 & & & & \\
\hline Elevation & -0.93 & 1.00 & & & \\
\hline MAT & 0.94 & -1.00 & 1.00 & & \\
\hline MAP & -0.92 & 0.94 & -0.94 & 1.00 & \\
\hline Litterfall & 0.85 & -0.81 & 0.85 & -0.65 & 1.00 \\
\hline
\end{tabular}
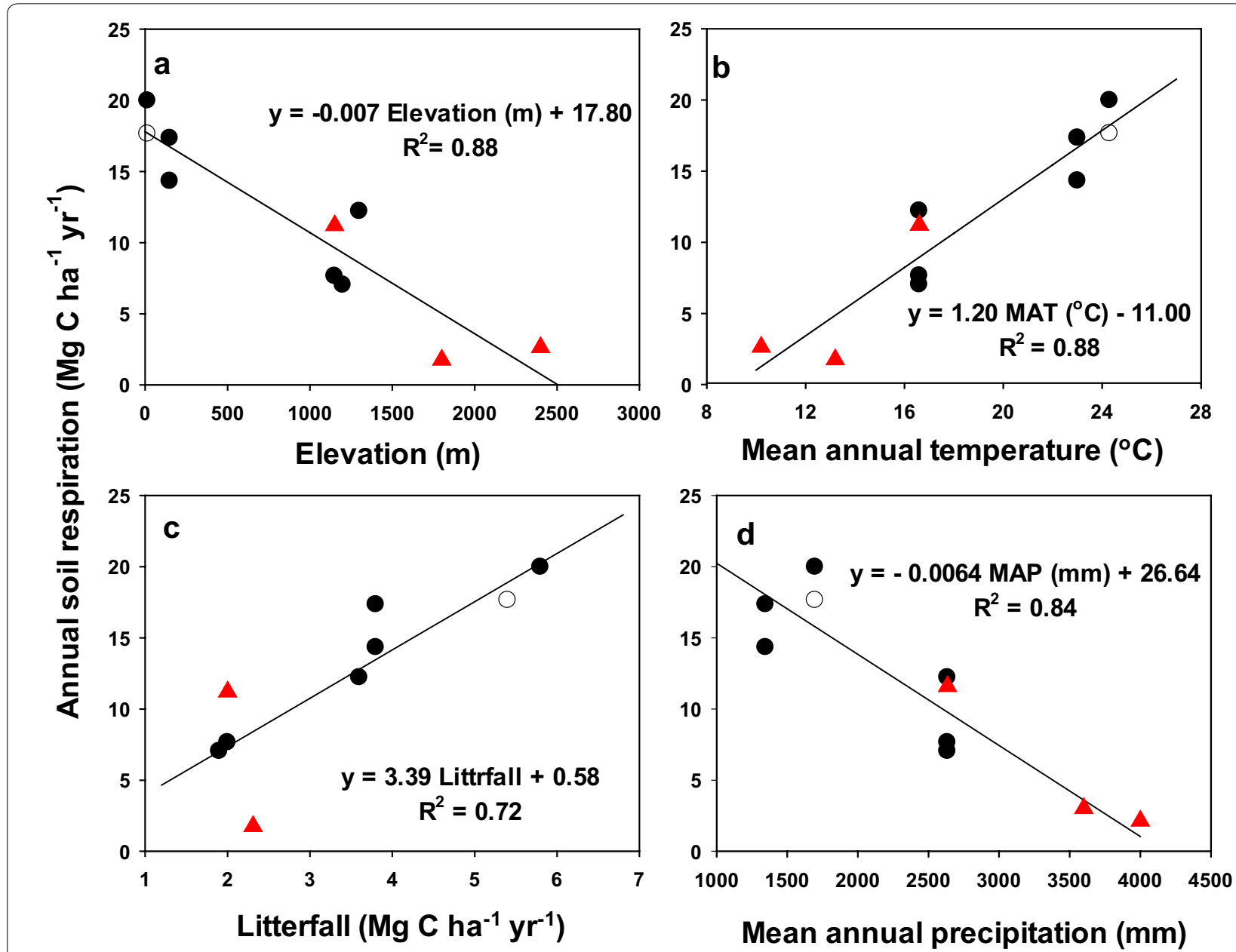

Fig. 4 Linear relationships of annual soil respiration with $\mathbf{a}$ elevation, $\mathbf{b}$ mean annual temperature, $\mathbf{c}$ litterfall, and $\mathbf{d}$ mean annual precipitation in Taiwan. Black circles refer to the current study and red circles refer to previous studies (Chang et al. 2008; Kao and Chang 2009; Hsieh et al. 2016)

between 1.44 and 2.37 at the mid-elevation NT plantation. However, when considering soil water content in Eq. (3), lower $\mathrm{Q}_{10}$ values from 1.39 to 2.69 at $\mathrm{TN}$ and TC plantations and a higher $\mathrm{Q}_{10}$ value from 1.92 to 3.60 at NT plantation were found. This finding suggested that the responses of soil respiration to soil temperature were confounded by soil water content.
Annual soil respiration rates at different plantations

Daily soil respiration rates calculated using the regression model [Eq. (3)] are shown in Fig. 3. The trend between measured and regression model are well corresponding, and the daily soil respiration variation could be found in the regression model. The annual soil respiration rates that summed by daily soil respiration rates were 
estimated as 17.6 and $20.0 \mathrm{Mg} \mathrm{C} \mathrm{ha}{ }^{-1}$ year $^{-1}$ at TN1 and TN2, 14.3 and $17.3 \mathrm{Mg} \mathrm{C} \mathrm{ha}^{-1}$ year $^{-1}$ at TC1 and TC2, and 7.6, 7.0, and 12.2 Mg Cha ${ }^{-1}$ year $^{-1}$ at NT1, NT2, and NT3, respectively (Table 3). Although variations were observed on the stand scale, higher annual soil respiration rates were observed at the lowland $\mathrm{TC}$ and $\mathrm{TN}$ plantations than at the mid-elevation NT plantation.

When combined with the finding of previous studies (Chang et al. 2008; Kao and Chang 2009; Hsieh et al. 2016), the annual soil respiration rates were strongly correlated with elevation, MAT, MAP, and litterfall production ( $\mathrm{p}<0.01$, Table 4 ), explaining 88,88 , 84 , and $72 \%$ of the variation in annual soil respiration, respectively (Fig. 4). Notably, the annual soil respiration rates increased by $1.2 \mathrm{MgC} \mathrm{ha}{ }^{-1}$ year $^{-1}$ for every $1{ }^{\circ} \mathrm{C}$ increase in MAT and by 3.4 $\mathrm{Mg} \mathrm{C} \mathrm{ha}^{-1}$ year $^{-1}$ for every 1-Mg C ha ${ }^{-1}$ year $^{-1}$ increase in litterfall production. By contrast, the annual soil respiration decreased by $0.7 \mathrm{Mg} \mathrm{C}$ ha $^{-1}$ year $^{-1}$ for every $100-\mathrm{m}$ increase in elevation and by $0.64 \mathrm{Mg} \mathrm{C} \mathrm{ha}^{-1}$ year $^{-1}$ for every 100 $\mathrm{mm}$ increase in MAP. Thus, higher annual soil respiration rates were found at the lowland plantations because of their higher MAT and litterfall production but lower MAP $(<1700 \mathrm{~mm})$. By contrast, lower annual soil respiration rates were found at the plantations at higher elevations because of their lower MAT and litterfall production but higher MAP (> $2500 \mathrm{~mm})$.

\section{Discussion}

\section{Effects of soil temperature and soil water content on soil respiration}

Soil temperature and soil water content are widely recognized as factors that control seasonal patterns of soil respiration (Raich and Schlesinger 1992; Saiz et al. 2006; Tang et al. 2006; Reichstein et al. 2003; Bond-Lamberty and Thomson 2010). In our study, we found that soil temperature or soil water content alone could somewhat account for the temporal pattern of soil respiration, and that the inclusion of both factors improved the predictive power of the model. The results suggested that the effects of the factors are interactive, rather than individual, for controlling the seasonal pattern of soil respiration. Generally, a higher soil respiration rate was observed in the hot and humid summer, whereas a lower soil respiration rate was observed in the cold and dry season.

Soil temperature and soil water content affected soil respiration differently. Soil temperature was positively correlated with the soil respiration rate at all three plantations. Soil water content was positively correlated with soil respiration at the lowland plantations but was negatively correlated at the mid-elevation plantation. We interpreted this finding as follows: soil water content at the lowland plantations was insufficiently high to reach the oxygen limitation for impeding soil respiration, whereas soil respiration at the mid-elevation plantation was inhibited by abundant precipitation (Davidson et al. 1998). Chang et al. (2008) and Hsieh et al. (2016) have reported the similar results of decreasing soil respiration with increasing soil water content in mountainous areas in Taiwan. Such a bidirectional relationship between soil water content and soil respiration has been previously observed on the watershed scale with a complex terrain or hydrological drainage (Riveros-Iregui et al. 2012; Knowles et al. 2015; Berryman et al. 2015). Our study provides the first evidence of a bidirectional relationship over an elevation gradient caused by different precipitation patterns.

The estimated $\mathrm{Q}_{10}$ values ranging between 1.44 and 3.31 were consistent with the global median value of 2.4 (Raich and Schlesinger 1992). The lower $\mathrm{Q}_{10}$ values at NT were possibly due to the oxygen limitation during summer, which rendered soil respiration less responsive to temperature (Davidson et al. 1998). When soil water content was added to the model, the $\mathrm{Q}_{10}$ values at NT increased from $1.44-2.37$ to $1.92-3.60$. The $\mathrm{Q}_{10}$ values at NT derived from the soil temperature and soil water content model [Eq. (3)] may be more accurate in representing the temperature dependence of soil respiration because the model considered the confounding effects of soil water content. However, the $\mathrm{Q}_{10}$ values at TN and TC derived from the combined soil temperature/soil water content model decreased from 2.44-3.31 to 1.39-2.69. The reduced $\mathrm{Q}_{10}$ values may have been masked by the correlation between soil temperature and soil water content (Tang et al. 2006).

\section{Annual soil respiration rates}

The average annual soil respiration rates at $\mathrm{TN}, \mathrm{TC}$, and NT were estimated as 19,16 , and $10 \mathrm{Mg} \mathrm{C} \mathrm{ha}^{-1}$ year $^{-1}$, respectively. The annual soil respiration rates at $\mathrm{TN}$ and $\mathrm{TC}$ are consistent with those reported for other tropical forests such as the Amazon rainforest and those in Thailand, Malaysia, and Hawaii (Davidson et al. 2000; Hashimoto et al. 2004; Katayama et al. 2009; Litton et al. 2011). This finding indicated that both plantations are highly productive. In fact, the annual soil respiration rates at TN and TC are high compared with the rates reported by numerous studies worldwide (Raich and Schlesinger 1992; Bond-Lamberty and Thomson 2010). This result indicated that the rates at these plantations are significant to global soil respiration models. The annual soil respiration rate at NT is high compared with those recorded at Japanese cedar plantations in Japan (Shutou and Nakane 2004; Lee et al. 2006), possibly because of the higher annual temperature and active plant growth rates at NT (Cheng et al. 2013b). 
In the present study, tight linkages were observed among annual soil respiration, elevation, MAT, MAP, and litterfall production at Taiwanese forest plantations (Table 4; Fig. 4). These results were expected because both abiotic (temperature and precipitation) and biotic (litterfall production) factors are critical drivers of soil respiration (Raich and Schlesinger 1992; Reichstein et al. 2003; Bond-Lamberty and Thomson 2010). The MAT, MAP, and litterfall production at all plantations were correlated with elevation (Fig. 4). Thus, elevation can be considered the main determinant factor influencing MAT, MAP, and primary production and defining the magnitude of the soil respiration rate. Previous studies have similarly reported that elevation is a crucial factor controlling the soil respiration rate (Kane et al. 2003; Litton et al. 2011; Berryman et al. 2014). Based on Fig. 4a, the annual soil respiration rate decreased by $0.7 \mathrm{Mg} \mathrm{C}^{-1}$ for every $100-\mathrm{m}$ increase in elevation. However, such a relationship may be modified if the findings of new studies are added. For example, Raich and Tufekcioglu (2000) suggested that soil respiration rates in coniferous forests are $10 \%$ lower than those in broad-leaved forests. Broadleaved forests in mountainous areas were not included in the present study.

In addition to climatic influence, differences in stand characteristics such as species composition, stand production, soil properties, and disturbances contribute to the variation in soil respiration (Raich and Tufekcioglu 2000; Tang et al. 2006; Bond-Lamberty and Thomson 2010; Sheng et al. 2010). In the present study, higher soil respiration rates at TN2 and NT3 might be because of their larger litterfall production and active plant growth rates (Table 1) (Lin et al. 2011; Cheng et al. 2013b). The higher soil respiration rate at TC2 was likely due to the invasive grass that accelerated the turnover rate of soil organic matter (Liao et al. 2008; Ward et al. 2009).

\section{Conceptual model for soil respiration in Taiwan}

A conceptual model of biotic and abiotic factors affecting soil respiration was developed to improve the understanding of soil respiration in Taiwan. We proposed three determinant factors influencing soil respiration patterns and rates: (i) elevation, (ii) stand characteristics, and (iii) soil temperature and soil moisture.

(i) Elevation On the interregional scale, elevation significantly affected MAT, MAP, and primary production and thus defined the magnitude of the soil respiration rate. Higher annual soil respiration rates were found at lowland plantations, whereas lower annual soil respiration rates were found at the plantations at higher elevations.

(ii) Stand characteristics On the stand scale, differences in stand characteristics exerted further influence on the soil respiration rate. In this study, larger litterfall production, active plant growth rates, and invasive grass tended to enhance soil respiration rates.

(iii) Soil temperature and soil water content On the temporal scale, soil respiration rates were found to be driven by the seasonality of soil temperature and soil water content. The soil respiration rates were higher in the hot and humid season than in the cold and dry season. The combined soil temperature and soil water content model indicated that soil temperature positively contributed to the soil respiration rate. In addition, a bidirectional relationship was observed between soil respiration and soil water content. At the lowland plantations, higher soil water content led to higher soil respiration, whereas excessive amounts of water at the mid-elevation plantation limited the oxygen supply, yielding lower soil respiration.

Based on the conceptual model, we anticipate that climate change will play a significant role in the responses of soil respiration to the determinant factors. In the scenario of global warming, rising temperatures can induce higher soil respiration. Changes in precipitation patterns may also affect soil respiration. Drying at mid-elevation might lead to the release of more soil organic carbon into the atmosphere; therefore, causing a shift from a carbon sink to a carbon source. Because of the high variability of soil respiration, more studies and data syntheses are required to accurately predict soil respiration in Taiwanese forests.

\section{Conclusions}

Soil temperature and soil water content are widely recognized as factors that control the seasonal patterns of soil respiration. The study results suggested that the effects of soil temperature and soil water content are interactive, rather than individual, for controlling the seasonal pattern of soil respiration. A combined soil temperature and soil water model explained $54-80 \%$ of the seasonal variations. However, these two factors affected soil respiration differently. Soil temperature positively contributed to soil respiration at all three plantations, and a bidirectional relationship between soil respiration and soil water content was observed among different plantations. Higher soil moisture content at $\mathrm{TN}$ and $\mathrm{TC}$ resulted in higher soil respiration rates; however, higher soil water content at NT led to adverse effects. The average annual soil respiration rates at TN, TC, and NT were estimated as 19, 16 , and $10 \mathrm{MgC} \mathrm{ha}^{-1}$ year $^{-1}$, respectively. When assembled with the findings of previous studies, tight linkages were observed among annual soil respiration, elevation, MAT, MAP, and litterfall production. Higher annual soil respiration rates were found at the lowland plantations because of their higher MAT and litterfall production but lower MAP. By contrast, lower annual soil respiration rates were found at the plantations at higher elevations 
because of their lower MAT and litterfall production and higher MAP. We proposed three determinant factors affecting soil respiration patterns and rates: (i) elevation, (ii) stand characteristics, and (iii) soil temperature and soil moisture. Based on the conceptual model, we anticipate that climate change will play a significant role in the future responses of soil respiration to the aforementioned factors. Because of the high variability of soil respiration, more studies and data syntheses are required to accurately predict soil respiration in Taiwanese forests.

\section{Authors' contributions}

$\mathrm{YHH}, \mathrm{CYH}$, and CHC planned the study, analyzed the data and developed the paper. IRL, KT, and OVM aided the field study and provided input to the manuscript. All authors read and approved the final manuscript.

\section{Author details}

${ }^{1}$ School of Forestry and Resource Conservation, National Taiwan University, Taipei 106, Taiwan. ${ }^{2}$ Institute of Forest Research RAI SR, Krasnoyarsk 660036, Russia.

\section{Acknowledgements}

We gratefully acknowledge Chang-Ya Chen and Hong-Jai Ruan for their assistance with field and laboratory work.

\section{Competing interests}

The authors declare that they have no competing interests.

\section{Availability of data and materials}

Data will be available.

\section{Consent for publication}

Not applicable.

\section{Ethics approval and consent to participate}

All authors accept complete responsibility for the contents of the manuscript. We take the responsibility that the manuscript has not been previously published, is not currently submitted for review to any other journal, and will not be submitted elsewhere before one decision made. We have agreed to participate.

\section{Funding}

This study was supported by the Ministry of Science and Technology of Taiwan and a cooperative grant from the National Science Council of Taiwan and the Siberian Branch of the Russian Academy of Sciences.

\section{Publisher's Note}

Springer Nature remains neutral with regard to jurisdictional claims in published maps and institutional affiliations.

Received: 7 August 2017 Accepted: 9 November 2017

Published online: 15 November 2017

\section{References}

Berryman EM, Marshall JD, Kavanagh K (2014) Decoupling litter respiration from whole-soil respiration along an elevation zone in a Rocky Mountain mixed-conifer. Can J For Res 44:432-440

Berryman EM, Barnard HR, Adams HR, Burns MA, Gallo E, Brooks PD (2015) Complex terrain alters temperature and moisture limitations of forest respiration across a semiarid to subalpine gradient. J Geophys Res-Biogeo 120:707-723

Bond-Lamberty B, Thomson A (2010) A global database of soil respiration data. Biogeosciences 7:1915-1926
Chang SC, Tseng KH, Hsia YJ, Wang CP, Wu JT (2008) Soil respiration in a subtropical montane cloud forest in Taiwan. Agric For Meteorol 148:788-798

Cheng CH, Chen YS, Huang YH, Chiou CR, Lin CC, Menyailo OV (2013a) Effects of repeated fires on ecosystem $C$ and $N$ stocks along a fire induced forest/grassland gradient. J Geophys Res-Biogeo 118:215-225

Cheng CH, Hung CY, Chen CP, Pei CW (2013b) Biomass carbon accumulation in aging Japanese cedar plantations in Xitou, central Taiwan. Bot Stud 54:60

Cheng CH, Huang YS, Menyailo OV, Chen CT (2016a) Stand development and aboveground biomass accumulation in cropland afforestation in Taiwan. Taiwan J For Sci 31:105-118

Cheng CH, Hsiao SC, Huang YS, Hung CY, Pai CW, Chen CP, Menyailo OV (2016b) Landslide-induced changes of soil physicochemical properties in Xitou, Central Taiwan. Geoderma 265:187-195

Davidson EA, Janssens IA (2006) Temperature sensitivity of soil carbon decomposition and feedbacks to climate change. Nature 440:165-173

Davidson EA, Belk E, Boone RD (1998) Soil water content and temperature as independent or confounded factors controlling soil respiration in a temperate mixed hardwood forest. Glob Change Biol 4:217-227

Davidson EA, Verchot LV, Henrique Cattânio J, Ackerman IL, Carvalho JEM (2000) Effects of soil water content on soil respiration in forests and cattle pastures of eastern Amazonia. Biogeochemistry 48:53-69

Hashimoto S, Tanaka N, Suzuki M, Inoue A, Takizawa H, Kosaka I, Tanaka K, Tantasirin C, Tangtham N (2004) Soil respiration and soil $\mathrm{CO}_{2}$ concentration in a tropical forest, Thailand. J For Res 9:75-79

Hsieh IF, Kume T, Lin MY, Cheng CH, Miki T (2016) Characteristics of soil $\mathrm{CO}_{2}$ efflux under an invasive species, Moso bamboo, in forests of central Taiwan. Tree 30:1749-1759

Janssens IA, Lankreijer H, Matteucci G, Kowalski AS, Buchmann N, Epron D, Pilegaard K, Kutsch W, Longdoz B, Grunwald T, Montagnani L, Dore S, Rebmann C, Moors EJ, Grelle A, Rannik U, Morgenstern K, Oltchev S, Clement R, Gudmundsso J, Minerbi NS, Berbigier P, Ibrom A, Moncrieff J, Aubinet M, Bernhofer C, Jensen NO, Vesala T, Granier A, Schulze ED, Lindroth A, Dolman AJ, Jarvis PG, Ceulemans R, Valentini R (2001) Productivity overshadows temperature in determining soil and ecosystem respiration across European forests. Glob Change Biol 7:269-278

Kane ES, Pregitzer KS, Burton AJ (2003) Soil respiration along environmental gradients in Olympic National Park. Ecosystems 6:326-335

Kao WY, Chang KW (2009) Soil CO2 efflux from a mountainous forest-grassland ecosystem in central Taiwan. Bot Stud 50:337-342

Katayama A, Kume T, Komatsu H, Ohashi M, Nakagawa M, Yamashita M, Otsuki K, Suzuki M, Kumagai T (2009) Effect of forest structure on the spatial variation in soil respiration in a Bornean tropical rainforest. Agric For Meteorol 149:1666-1673

Knowles JF, Blanken PD, Williams MW (2015) Soil respiration variability across a soil moisture and vegetation community gradient within a snow-scoured alpine meadow. Biogeochemistry 125:185-202

Law BE, Ryan MG, Anthoni PM (1999) Seasonal and annual respiration of a ponderosa pine ecosystem. Glob Change Biol 5:169-182

Lee PF, Ding TS, Hsu FH, Geng S (2004) Breeding bird species richness in Taiwan: distribution on gradients of elevation, primary productivity and urbanization. J Biogeogr 31:307-314

Lee MS, Mo WH, Koizumi H (2006) Soil respiration of forest ecosystems in Japan and global implications. Ecol Res 21:828-839

Liao C, Peng R, Luo Y, Zhou X, Wu X, Fang C, Cheng J, Li B (2008) Altered ecosystem carbon and nitrogen cycles by plant invasion: a meta-analysis. New Phytol 177:706-714

Lin YR, Cheng CH, Tseng TY (2011) Carbon sequestration potential of afforestation in the plain areas in Taiwan: examples from longterm abandoned orchards and afforested sites. Quart J Chin For 44:567-588 (In Chinese)

Litton CM, Giardina CP, Albano JK, Long MS, Asner GP (2011) The magnitude and variability of soil-surface $\mathrm{CO} 2$ efflux increase with mean annual temperature in Hawaiian tropical montane wet forests. Soil Biol Biochem 43:2315-2323

Lloyd J, Taylor JA (1994) On the temperature dependence of soil respiration. Funct Ecol 8:315-323

Raich JW, Schlesinger WH (1992) The global carbon dioxide flux in soil respiration and its relationship to vegetation and climate. Tellus 44:81-99

Raich JW, Tufekcioglu A (2000) Vegetation and soil respiration: correlations and controls. Biogeochemistry 48:71-90 
Reichstein M, Rey A, Freibauer A, Tenhunen J, Valentini R, Banza J, Casals P, Cheng Y, Grunzweig JM, Irving J, Joffre R, Law BE, Loustau D, Miglietta F, Oechel W, Ourcival J, Pereira JS, Peressotti A, Ponti F, Qi Y, Rambal S, Rayment M, Romanya J, Rossi F, Tedschi V, Tirone G, Xu M, Yakir D (2003) Modeling temporal and large-scale spatial variability of soil respiration from soil water availability, temperature and vegetation productivity indices. Glob Biogeochem Cycles 17:1104

Riveros-Iregui DA, McGlynn BL, Emanuel RE, Epstein HE (2012) Complex terrain leads to bidirectional response of soil respiration to inter-annual water availability. Glob Change Biol 18:749-756

Saiz G, Byrne KA, Butterbach-Bahl K, Kiese R, Blujdea V, Farrell EP (2006) Stand age-related effects on soil respiration in a first rotation Sitka spruce chronosequence in central Ireland. Glob Change Biol 12:1007-1020

Sheng H, Yang Y, Yang Z, Chen G, Xie J, Guo J, Zou S (2010) The dynamic response of soil respiration to land-use changes in subtropical China. Glob Change Biol 16:1107-1121

Shutou K, Nakane K (2004) Change in soil carbon cycling for stand development of Japanese cedar (Cryptomeria japonica) plantations following clear-cuttting. Ecol Res 19:233-244
Tan ZH, Zhang YP, Liang N, Song QH, Liu YH, You GY, Li LH, Yu L, Wu CS, Lu ZY, Wen HD, Zhao JF, Gao F, Yang LY, Song L, Zhang YJ, Munemasa T, Sha LQ (2013) Soil respiration in an old-growth subtropical forest: patterns, components, and controls. J Geophys Res-Atmos 118:1-10

Tang XL, Zhou GY, Liu SG, Zhang DQ, Liu SZ, Li J, Zhou CY (2006) Dependence of soil respiration on soil temperature and soil moisture in successional forests in southern China. J Integr Plant Biol 48:654-663

Ward SE, Bardgett RD, McNamara NP, Ostle NJ (2009) Plant functional group identify influences short-term peatland ecosystem carbon flux: evidence from a plant removal experiment. Funct Ecol 23:454-462

\section{Submit your manuscript to a SpringerOpen ${ }^{\odot}$ journal and benefit from:}

- Convenient online submission

- Rigorous peer review

- Open access: articles freely available online

- High visibility within the field

- Retaining the copyright to your article

Submit your next manuscript at $\boldsymbol{\nabla}$ springeropen.com 